\title{
Marketing Mix of Ecotourism Product in Kuching, Sarawak, Malaysia
}

\author{
Er, A.C. ${ }^{1}$ \\ Sherly Simon ${ }^{2}$ \\ ${ }^{1}$ Professor, Faculty of Social Sciences and Humanities, Universiti Kebangsaan Malaysia \\ eveer@ukm.edu.my \\ ${ }^{2}$ Research officer, Faculty of Social Sciences and Humanities, Universiti Kebangsaan Malaysia
}

\section{Doi:10.5901/mjss.2015.v6n4s3p39}

\section{Abstract}

Entrepreneurship and formation of new businesses are important in creating and maintaining a competitive economy. The main purpose of this research is to examine the demographic and business profile of the ecotourism operators and identify the relationship that takes place between the 4P marketing strategy (product, prices, promotion and places) with market competitiveness in terms of cost control, competitive challenges, quality of service, tourist arrival statistics and agency's role. This research will identify the aspects in the 4P marketing strategy that will have impact on the competitiveness of the market. This study was carried out in Kuching, Sarawak; however, only 4 areas of ecotourism around Kuching were selected which are Waterfront Kuching, Sarawak Cultural Village, Bukit Santubong, and Damai Beach Resort. The respondents for this study were ecotourism operators, and a total of 86 operators were involved in this research. The processed data were analysed using Spearman correlation analysis and cross tab. Results of the study showed that the majority of the ecotourism operators are women and the type of business conducted is service oriented. The aspects of promotion, product, price and place marketing have influenced the competitiveness of the ecotourism market in Kuching, Sarawak.

Keywords: Entrepreneurship, formation of businesses, ecotourism operators, marketing strategy

\section{Introduction}

Sarawak is targeting the entry of 4 million tourists compared to 3 million in 2011 (Sarawak Corridor of Renewable Energy, 2012). The tourism industry in Sarawak can be strengthened because of various factors. One of them is the development of the ecotourism industry in Sarawak which is well known for its natural heritage and its cultural uniqueness. Realising the potential of ecotourism in Sarawak that is capable of giving good return toward the economic development of Sarawak, the Chief Minister of Sarawak recently suggested that the Bumiputera entrepreneurs involved in the tourism sector be brought together or assembled in one entity to strengthen further their dominance in the ecotourism industry.

Tourism has contributed Gross National Income revenue totalling RM56.2 billion and will be generating employment opportunities to 28,895 people in Sarawak by the year 2020. As we know, tourism is an important source of income generated from foreign exchange that contributes to the economy of Malaysia during the decline of commodity prices and provides five percent of the workforce recruitment. Hence, the government plays an important role in promoting tourism (Alister \& Wall, 1991).

Ecotourism is the most important sector for Sarawak in the effort to make the state as one of the high income states. Various ecotourism attractions are available in Sarawak that still preserves its heritage, nature, beautiful environment and its rich culture. In addition, many activities can be carried out in the ecotourism areas that have potential to contribute higher earnings to the people and the state of Sarawak. However, the present development of ecotourism entrepreneurial activities depends on the current situation of the global economy that is difficult to predict because of the various incidents that have taken place in the past decades.

The integration between the tourism sector and nature creates ecotourism activities that are based on natural resources. Ecotourism refers to visits to appreciate the relationship of organisms with the environment that is still unspoilt. In detail, ecotourism can be summarised as activities that bring the tourists closer to the environment, where they can take part, be entertained and feel the excitement of learning, visiting and finding something new based on nature or the environment (Lee Kuok Tiung, 2010).

The activities of tourism entrepreneurship have been proven to be capable of contributing a large sum of foreign exchange to the country, apart from playing the role of creating employment opportunities through a variety of related 
sectors such as the hotel and transport sectors. Nevertheless, the current development of tourism entrepreneurship activities depend on the existing global economic situation that is difficult to predict. The ecotourism industry requires great and solid promotion. Creativity and innovation on the ecotourism products and services can attract even more tourists.

There are many entrepreneurial elements in ecotourism in Sarawak. For example, the modes of transport in the tourism industry can be diversified such as ships, boats, excursion buses, and rental cars. For the accommodation sector, there are hotels, motels, resorts, chalets and homestays. These attractions have resulted in the increase of ecotourism's added value. Therefore, this research will examine further the attractions that contribute to the business activities in the study area and subsequently its impact on the socio-economy of the local people. Hence, the tourism entrepreneurs should be exposed to the knowledge, experience, and current information that is relevant and up to date so that they are more sensitive in coping with the current issues, as well as sensitive to the current challenges and competition in the ecotourism industry.

Effective marketing strategy is important in boosting the growth of ecotourism based economy. Marketing of ecotourism destinations or places is considered successful if consumerism increases and consumers feel satisfied, while the operators will receive optimum profit with minimal risk. Application of marketing strategy allows the destination to have the advantage of being highly competitive. Ecotourism destinations should create products and services that are up-todate and in line with the requirements and needs of the tourists as well as market them at the local and global scale. In order to obtain or attain comparative advantage and competitive advantage either at the local or international level, ecotourism entrepreneurship should always be innovative and creative so that an ecotourism destination can create its own advantage, as well as being unique and different. Development of products and services that are more innovative should be encouraged in order to meet the differing interests and tastes among the tourists, prolong the length of stay and increase the expenditure of the local and foreign tourists.

In addition, travel and tour agencies are encouraged to improve the design, attractiveness and the marketing of tourism packages by giving attention to specific interests, quality and price to meet the various demands of the tourists (9th Malaysia Plan).

Marketing cannot be separated from the 4 components of marketing (4P), namely product, price, promotion and place. The marketing strategy that has been introduced by Jerome McCarthy in 1960 is still being used until the present day. Brian Tracy has included 3 new elements in the marketing component strategy, namely packaging, positioning, and people. Nevertheless, this research is only focused on the four basic aspects of marketing mix which are product, price, promotion and place and their relationship with market competitiveness in Kuching, Sarawak.

\section{Literature Review}

The results discussed are the outcome of several initial visits which utilised observation and fieldwork approaches that were designed so that they could provide description of the current situation of the study location. This is also stated study by Badaruddin et al. (2009) on the place attributes needed to ensure the level of competitiveness to make initial description of the source of attractions and tourism activities to increase the competitiveness of Lenggong Valley as a leading tourism location.

The term marketing mix is used widely after Neil $\mathrm{H}$. Borden published his article titled 'The Concept of the Marketing Mix' in 1964. He characterised marketing mix into 12 components, namely product planning, pricing, distribution channel, personal selling, advertising, promotions, packaging, display, servicing, physical handling, and fact finding and analysis. Later, Jerome McCarthy integrated all these elements into 4 categories that are also known as the 4P of marketing mix which are product, promotion, prices and places.

A number of tourists are not satisfied with the price offered for some of the tour packages. This is because there are significant price differences for each agency according to the specified time. Even though many packages are offered such as the Payar Island package, the mangrove package, in terms of price coordination, it is still not satisfactory. This matter needs to be given attention to avoid the problem of lack of customers as a result of price volatility. Therefore, price plays an important role in attracting the arrival of tourists, and subsequently guaranteeing the competitiveness of the sector through the active participation of the public and private sectors that drive the promotion and marketing, diversifying the targeted market (Rosniza Aznie et al. 2012).

Networking between firms in the sector is important for social capital (Burt, 2000). This network takes place in a wider context including involving the exchange of information, loan of equipment, exchange of ideas and suggestions. Networking such as this normally occurs in specific Small and Medium Industries sector (Blundel \& Smith, 2001).

In the study carried out by Nor Aini Haji Idris and Faridah Shahadan (2009) titled "Analysis of Quality System in the 
Context of Status and Performance: Case Study of Agro-Based Small and Medium Industries", the focus was on the quality system that is considered one of the important aspects that needs to be given attention by entrepreneurs. The discussion was based on the findings of the study which was carried out on 237 SMI agro-based firms. In addition, the discussion also involved the relationship of the quality system with the important variables in business such as financial management and marketing and comparison of quality systems between successful and unsuccessful companies.

The study conducted by Mohd Ashari Idris and Aliah Hanim (2002) titled "Building Integration Between the Core Elements of TQM (Total Quality Management) with Market Orientation and Its Relationship with the Performance of the Firm" has developed an integrated model that will explain how to generate competitive advantage for the firm. One of the aspects that is emphasised is the high cost of production and control of product cost. The firm emphasises internal efficiency and objectives that have connection with the effort to reduce production cost and marketing cost.

Next is the study conducted by Shahrin Hashim and Shaiful Nizam (2007) titled "Promotional Strategy of Stall Traders at Convocation Festival" which examined the elements in marketing mix, namely advertising, publicity, direct sales, and sales promotion that were the most dominantly used by the traders to increase their sales at the convocation festival of UTM, Skudai. Questionnaires were distributed and the findings showed that direct sales was the most dominant element in the promotional mix strategy followed by publicity, advertising and sales promotion. Therefore, it can be concluded that competition in the market, especially promotion is an important factor that should be taken into account in determining the success of an organisation in order to achieve the desired goals.

This research was conducted by Er Ah Choy et al. (2012) in Ulu Dong, Raub, Pahang. The purpose of the research was to identify the potential of ecotourism development in Lata Jarum based on the Diamond Porter Model (1990). The model analysed the determinants of competitive advantage such as factor conditions, demand conditions, support related industries as well as firm strategies, structure and competition. The method used in this research was interview and key informant method which included the village head, chalet operators, the developers, as well as government officers from Raub District Council, and Raub Land and District Office.

The place or distribution channel is the operator's activity to ensure that the product is always available in the market by using the services of middlemen, retail and wholesale services, and strategic location to market the services and product (Larry Steven, 2009). Therefore, in this study, the place marketing that is to be studied include variables such as distribution channel, middlemen services, tourist accessibility, competition and the infrastructure of the place marketing.

\section{Research Problem}

In the context of ecotourism products, Sarawak has its own beautiful natural attractions that are very suitable for extreme sports such as kayaking, mountain climbing, and many others, but they are still not well known, particularly among foreign tourists. Sarawak also has many ecotourism products but they still need to be promoted and documented more intensely (Borneo Post, 2011). When the tourism products depend entirely on local culture and the natural resources, it requires the best possible participation from the local community to manage it (Lilywhite, 1991).

Meanwhile in the aspect of Sarawak's ecotourism product promotion, it was found that there are several tourist agencies that are not serious in promoting the interesting products and destinations that can be found in Sarawak. In addition, the number of tourist agencies that are involved in related conferences organised overseas is small. This situation has resulted in foreign tourists not to know much about Sarawak compared to Sabah and several other states in Peninsular Malaysia (Borneo Post, 2012). Some of the tourist agencies refused to fork out large expenses to pay for airfare and accommodation to attend any conference and marketing of ecotourism products abroad. Nevertheless, Sarawak will boost its efforts in promoting ecotourism products through close cooperation between the Ministry of Tourism, Sarawak Tourist Board and Sarawak Tourism Federation. The purpose of this study therefore, is to examine the relationship between marketing mix and competitiveness of the ecotourism market.

\section{Research Method}

The respondents for the study were operators who are involved in the business of service based on ecotourism around the city of Kuching, Sarawak. Due to the absence of specific information about the actual number of operators in the study area, the researcher therefore had carried out a census to determine the number of active traders or operators in the vicinity of the research area. Table 1 shows the enumeration result of the census on the number of ecotourism operators 
Table 1. Number of Ecotourism Operators

\begin{tabular}{lc}
\hline Study Area & Number of Population \\
\hline Waterfront, Kuching & 17 \\
Damai Beach Resort & 19 \\
Mount Santubong & 15 \\
Sarawak Cultural Village & 35 \\
\hline Total Number of Population & $\mathbf{8 6}$ \\
\hline
\end{tabular}

Source: Fieldwork, 2013

\section{Results and Discussion}

\subsection{Structure of Business Ownership}

The results of the study show that the structure of ownership for the business conducted was mostly in the form of private limited companies which was 29 companies (33.7\%), followed by limited companies at $23(26.7 \%)$ while partnership companies was 19 (22.1\%) and the least was individual/private type of company with a total of 15 companies (17.4\%).

Table 2. Structure of Business Ownership

\begin{tabular}{lcc}
\hline Business Structure & Number of Companies/Operators & Percentage (\%) \\
\hline Individual/Private & 15 & 17.40 \\
Limited Company & 23 & 26.70 \\
Private Limited Company & 29 & 33.70 \\
Partnership & 19 & 22.10 \\
\hline & 86 & 100.00 \\
\hline
\end{tabular}

Source: Fieldwork 2013

\subsection{Type of Business}

The research shows that business of the tourism, eatery and retail trade type of company are the ones mostly carried out by the operators. This is because during each visit, tourists are really in dire need of services like drivers, holiday planners, tourist guides, food and beverages, transport, and souvenir. Tourism companies or tourist agents are the primary or main type of business in Kuching to help with tourists' holiday plans or visitation of overseas delegation to Sarawak. Table 3 explains the number of business types found in the research area.

Table 3. Type of Business

\begin{tabular}{lcc}
\hline Type of Business & Number of Operators & Percentage (\%) \\
\hline Accommodation & 13 & 15.10 \\
Services (restaurant/catering) & 19 & 22.10 \\
Transportation & 14 & 16.30 \\
Tourism Agency (Guide) & 22 & 25.60 \\
Retail & 18 & 17.80 \\
\hline & 86 & 100.00 \\
\hline
\end{tabular}

Source: Fieldwork, 2013

\subsection{Capital Distribution}

The lowest capital distribution is RM50, 000-RM99, 999.00 which is a total of 5 companies or operators (5.0 percent). This proves that the majority of the operators did not use very large initial capital to run their business. The capital distribution depends on the product offered and the expected profit from the sale. Capital distribution which involved 
amount that is less than RM1000 is normally owned by the individual or private type of business. Table 4 presents the rest of the capital distribution including the number of operators involved.

Table 4. Capital Distribution

\begin{tabular}{ccc}
\hline Capital (RM) & Number of Operators & Percentage (\%) \\
\hline$<1000$ & 9 & 10.50 \\
$1000-9,999.00$ & 30 & 34.90 \\
$10,000-24,999.00$ & 27 & 31.40 \\
$25,000-49,999.00$ & 15 & 17.40 \\
$50,000-99,999.00$ & 5 & 5.00 \\
\hline & 86 & 100.00 \\
\hline
\end{tabular}

Source: Fieldwork, 2013

\subsection{Advertising Channel}

The study found that the advertising channel frequently used by the operators is through the internet and social sites, which is a total of 24 operators (27. 9 percent), followed by direct marketing at 19 (18.8 percent), and next through the radio and television station, namely 17 (19.8 percent). The advertising channel that is least used is the electronic print media which is 10 operators (11.6 percent). The operators mainly used the internet and social media such as Facebook and blogs to introduce or promote the products and services that they offer because tourists preferred to access information through the internet.

Table 5. Advertising Channel

\begin{tabular}{lcc}
\hline Advertising Channel & Number of Operators & Percentage (\%) \\
\hline Electronic print media & 10 & 11.60 \\
Radio / Television Station & 17 & 19.80 \\
Internet / Social Media & 24 & 27.90 \\
Direct Market & 19 & 18.80 \\
Meet the Customer Day/Campaign & 16 & 15.80 \\
\hline & $\mathbf{8 6}$ & $\mathbf{1 0 0 . 0 0}$ \\
\hline
\end{tabular}

Source: Field Study, 2013

\subsection{Product and Competitiveness Correlation Analysis}

Table 6 explains the correlation between product and competitiveness. There are two factors in the category of initiative and two factors in the category of increase of sales which were tested with the three factors of competitiveness using the correlation analysis test.

Table 6. Product and Competitiveness Relationship

\begin{tabular}{|c|c|c|}
\hline Product & Competitiveness & Correlation Value \\
\hline $\begin{array}{l}\text { (i) Take into consideration the advantages and } \\
\text { disadvantages of competitors' product before marketing }\end{array}$ & $\begin{array}{l}\text { Capable of handling the challenges of business competition by } \\
\text { expanding the market network of the product sold }\end{array}$ & $.256^{\star}$ \\
\hline $\begin{array}{l}\text { Take into consideration the advantages and } \\
\text { disadvantages of competitors' product before marketing }\end{array}$ & $\begin{array}{l}\text { Create product cost control to remain competitive in the market } \\
\text { Continuously improving the quality of services and products according }\end{array}$ & 175 \\
\hline Take into consideration the advantages and & to the interests and preferences of tourists & .330 \\
\hline $\begin{array}{l}\text { disadvantages of the competitors' products before } \\
\text { marketing } \\
\text { (ii) I carry out product branding efforts }\end{array}$ & $\begin{array}{l}\text { Capable of handling the challenges of business competition by } \\
\text { expanding the market network of the product sold } \\
\text { Create product cost control to remain competitive in the market }\end{array}$ & 150 \\
\hline $\begin{array}{l}\text { I carry out product branding efforts } \\
\text { I carry out product branding efforts }\end{array}$ & $\begin{array}{l}\text { Continuously improving the quality of services and products according } \\
\text { to the interests and preferences of tourists }\end{array}$ & $.248^{*}$ \\
\hline $\begin{array}{l}\text { (iii) Ecotourism products are sold as a package to } \\
\text { enable tourists to experience many products at one }\end{array}$ & $\begin{array}{l}\text { Capable of handling the challenges of business competition by } \\
\text { expanding the market network of the product sold }\end{array}$ & .214 \\
\hline & & $.237^{*}$ \\
\hline
\end{tabular}




\begin{tabular}{|c|c|c|}
\hline Product & Competitiveness & Correlation Value \\
\hline $\begin{array}{l}\text { Ecotourism products are sold as a package to enable } \\
\text { tourists to experience many products at one time }\end{array}$ & Create product cost control to remain competitive in the market & .197 \\
\hline $\begin{array}{l}\text { Ecotourism products are sold as a package to enable } \\
\text { tourists to experience many products at one time }\end{array}$ & $\begin{array}{l}\text { Continuously improve the quality of services and products according to } \\
\text { the interests and preferences of tourists }\end{array}$ & .266 \\
\hline $\begin{array}{l}\text { (iv) Regularly attend additional courses to generate } \\
\text { creative ideas about the product }\end{array}$ & $\begin{array}{l}\text { Continuously improving the quality of services and products according } \\
\text { to the interests and preferences of tourists }\end{array}$ & $.230 *$ \\
\hline $\begin{array}{l}\text { Regularly attend additional courses to generate } \\
\text { creative ideas about the product }\end{array}$ & $\begin{array}{l}\text { Capable of handling the challenges of business competition by } \\
\text { expanding the market network of the product sold }\end{array}$ & .209 \\
\hline $\begin{array}{l}\text { Regularly attend additional courses to generate } \\
\text { creative ideas about the product }\end{array}$ & Create product cost control to remain competitive in the market & .172 \\
\hline
\end{tabular}

The correlation test between 'take into consideration the advantages and disadvantages of competitors' product before marketing the product' and 'capable of handling the challenges of business competition by expanding the market network of the product' showed very weak positive but significant value, namely $(r=.256, p<.05)$. This means initial research on the advantages and disadvantages of competitors' product influences the operators' preparation to face competition in expanding the product's market. The information helps the operators to make preliminary strategies to reduce the competition from other operators. For example, there are several water taxi operators in Kuching Waterfront who take passengers for cruises along the river to interesting places. These operators offer various promotions and reasonable prices to attract the attention of even more visitors. This is consistent with the results of a study on business competition by Open University (2005), where operators need to always inquire about the growth and progress of their competitors to remain in the market and expand their market size. Presently, competition is not only in terms of the existing competitors but also from the competitors who will emerge or new technology from the existing competitors.

Next, for the correlation test between 'take into consideration the advantages and disadvantages of competitors' product before marketing the product' and 'create product cost control to remain competitive in the market', the result showed a value that is not significant, namely $(r=.175)$ while with 'I continuously improve the quality of services and the product according to the interests and preferences of the tourists' also showed a non-significant value $(r=.330)$. This is because the advantages and disadvantages of ecotourism products in Kuching are diverse and different from one another resulting in cost control and quality of services that could not be measured based on one competitors' product only. It should take into account many factors of competition that are carried out by the competitors to enable the ecotourism products to be more competitive. Therefore, the advantages and disadvantages of the competitors' product do not affect or influence cost control and quality of ecotourism services.

Correlation test between 'I carry out product branding efforts' and 'create product cost control to remain competitive in the market' showed a very weak positive but significant value, namely $(r=.248, p<.05)$. For example, the cultural show in Sarawak Cultural Village that is rich in the traditional elements of the local Sarawak community is well-known among the tourists as a good brand to represent the culture and way of life of the community. This is consistent with the recommendations of the Tourism Minister, Datuk Seri Dr. Ng Yen Yen, who emphasised that tourism products should be given branding so that the quality offered is at par or equivalent to the international level. The services of tourist guides should be upgraded to a higher standard so that informative and friendly interactions can be created. If product branding is carried out, hence savings can be made on the production cost of the product such as marketing cost and advertising because the tourists would have known of the existence of the brand and quality of the product.

Correlation test between 'I carry out product branding efforts' and 'capable of handling the challenges of business competition by expanding the market network of the product' showed a non-significant value which is $(r=.150)$ while with 'I continuously improve the quality of services and the product according to the interests and preferences of the tourists', it also showed a non-significant value, namely $(r=.214)$. This is because only a few types of businesses in Kuching have succeeded in branding ecotourism products such as the 'Water Taxi' in Kuching Waterfront and cultural dance in Sarawak Cultural Village. Therefore, these two types of product have less competitive challenges from other businesses and do not influence the quality of services because ecotourism product branding in Kuching has set certain standards to enable an ecotourism product to be branded.

'Ecotourism product is sold as a package to enable tourists to experience many products at one time' and 'capable of handling the challenges of business competition by expanding the market network of the product sold' showed very weak positive but significant value, which is $(r=.237, p<.05)$. This indicates that ecotourism products that are sold as a package affect or influence the ability of the product to be marketed on a large scale. The role of Sarawak Tourist Association (STA) and other tourist agencies such as Borneo Adventure and Borneo Exploration Tours \& Travel is to manage and suggest places to be visited by the tourists and to explain the suitable packages as well as make 
reservations of accommodation. This is consistent with the results of the study by Habibah Ahmad et al. (2012) titled 'Packaging Tasik Chini tourism as Tasik Chini Biosphere Reserve' which have identified a few elements that can be used to package the Tasik Chini Biosphere Reserve tourism. The elements are the environment or nature, community, culture and economy. These elements can create ecotourism activities that can be carried out by the tourists and the surrounding community.

The correlation test between 'ecotourism product is sold as a package to enable tourists to experience many products at one time' and 'create product cost control to remain competitive in the market' indicated a value that is not significant $(r=.197)$ while with 'I continuously improve the quality of services and the product according to the interests and preferences of the tourists', it also showed a value that is not significant, namely ( $r=.266)$. According to one of the operators in Mount Santubung, there are many packages offered to tourists to experience adventure activities at reasonable prices. However, it does not influence the effort to carry out control of cost and service quality separately because the sale of products as a package has already included cost and quality control that has been agreed between the operators and the middlemen.

Next, the correlation test between 'regularly attend additional courses to generate creative ideas about the product' and 'capable of handling challenges of business competition by expanding the market network of the product sold' showed a positive value that is weak but significant $(r=.230, p<.05)$. This means that the additional courses organised by the Bumiputera entrepreneurs' organisation really influence the skills and knowledge of entrepreneurs in expanding the business direction of their product. In order to ensure that Bumiputera entrepreneurs are competitive, the government has organised various entrepreneurship seminars with the help from several government agencies such as Majlis Amanah Rakyat (MARA) or Council of Trust for the People, Ministry of International Trade and Industry (MITI), Malaysian Industrial Development Association (MIDA) and Development Bank. This seminar was conducted with the purpose of providing exposure to Bumiputera entrepreneurs to the latest market trend, ways of improving the quality of products and packaging as well as strengthening their marketing skills in promoting products and services effectively.

Correlation test between 'regularly attend additional courses to generate creative ideas about the product' and 'create product cost control to remain competitive in the market' showed a non-significant value, namely $(r=.209)$ while with 'I continuously improve the quality of services and the product according to the interests and preferences of the tourists', a non-significant value, which is ( $r=.172)$ was indicated. This is because the courses offered provided more guidance on how to expand or widen their business in general and less exposure on the aspects of method of cost control and service quality.

\subsection{Place Marketing and Competitiveness Correlation Analysis}

Table 7 explains the correlation between place marketing and competitiveness. There is one factor in the internal category and two factors in the external category that were tested with the three factors of competitiveness using the correlation analysis test.

Table 7. Place Marketing and Competitiveness Relationship

\begin{tabular}{|c|c|c|}
\hline Place Marketing & Competitiveness & Correlation Value \\
\hline $\begin{array}{l}\text { (i) Conduct preliminary research on the nature and } \\
\text { infrastructure of the product marketing location }\end{array}$ & $\begin{array}{l}\text { Capable of handling the challenges of business competition by } \\
\text { expanding the market network of the product sold }\end{array}$ & $.278^{\star \star}$ \\
\hline $\begin{array}{l}\text { Conduct preliminary research on the nature and infrastructure of } \\
\text { the product marketing location }\end{array}$ & $\begin{array}{l}\text { Create product cost control to remain competitive in the market } \\
\text { Continuously improving the quality of services and product }\end{array}$ & .063 \\
\hline $\begin{array}{l}\text { Conduct preliminary research on the nature and infrastructure of } \\
\text { the product }\end{array}$ & $\begin{array}{l}\text { according to the interests and preferences of tourists } \\
\text { Capable of handling the challenges of business competition by }\end{array}$ & .176 \\
\hline $\begin{array}{l}\text { marketing location } \\
\text { (ii) Place marketing prioritises the aspect of tourist accessibility }\end{array}$ & expanding the market network of the product sold & $-.274^{*}$ \\
\hline Place marketing prioritises the aspect of tourist accessibility & Create product cost control to remain competitive in the market & .144 \\
\hline Place marketing prioritises the aspect of tourist accessibility & $\begin{array}{l}\text { Continuously improving the quality of services and product } \\
\text { according to the interests and preferences of tourists }\end{array}$ & .192 \\
\hline $\begin{array}{l}\text { (iii) Product distribution channel is the key aspect to enable } \\
\text { products to be experienced by tourists }\end{array}$ & $\begin{array}{l}\text { Capable of handling the challenges of business competition by } \\
\text { expanding the market network of the product sold }\end{array}$ & $.299 * \star$ \\
\hline $\begin{array}{l}\text { Product distribution channel is the key aspect to enable } \\
\text { products to be experienced by tourists }\end{array}$ & $\begin{array}{l}\text { Create product cost control to remain competitive in the market } \\
\text { Continuously improving the quality of services and product }\end{array}$ & .106 \\
\hline $\begin{array}{l}\text { Product distribution channel is the key aspect to enable } \\
\text { products to be experienced by tourists }\end{array}$ & according to the interests and preferences of tourists & .178 \\
\hline
\end{tabular}

Note: Significant ${ }^{\star}{ }^{*} p<.01,{ }^{\star} p<.05$ 
For the correlation test between 'conduct preliminary research on the nature and infrastructure of the product marketing location' and 'I continuously improve the quality of services and products according to the interests and preferences of tourists', a positive value that is very weak but significant was found $(r=.278, p<.01)$. Ecotourism infrastructure facilities such as drainage, building structure, recreational facilities, information board, shorter routes, jogging tracks, and bridges will attract the tourists' attention. This statement is supported by Norlida et al. (2011) in relation to tourist satisfaction toward the quality of service, in that tourists' reaction toward the quality of infrastructure is important to be made a guide in developing and sustaining the destination as the main destination of tourist attraction.

Correlation test between 'conduct preliminary research on the nature and infrastructure of the product marketing location' and 'create product cost control to remain competitive in the market' showed a non-significant value ( $r=.065)$ while with 'I continuously improve the quality of services and product according to the interests and preferences of tourists', a non-significant value was also shown $(r=.176)$. This is because the operators' initial expectation on place marketing is only related to basic facilities to facilitate them in carrying out their daily activities. Therefore, it did not affect or influence cost control and the service quality of the ecotourism product.

Next, the correlation test between 'place marketing prioritises the aspect of tourist accessibility' and 'capable of handling the challenges of business competition by expanding the market network of the product sold' showed a very weak positive but significant value $(r=.274, p<.05)$. This means that the more facilities are provided for tourists to come to a tourist destination, the less challenges are faced by the operators in marketing their product. This is consistent with the results of a study by Redzuan Othman and Norlida Hanim (2007) where analysis of tourists' demand toward the tourist industry in Malaysia was found to be dependent on the rate of tourist accessibility and the availability of transportation facilities. Therefore, the operators need not make frequent advertising campaigns because transportation accessibility will always bring the tourists to the destination.

Correlation test between 'Place marketing prioritises the aspect of tourist accessibility' and 'create product cost control to remain competitive in the market' showed a non-significant value which is $(r=.144)$ while correlation with 'I continuously improve the quality of services and product according to the interests and preferences of tourists' also showed a non-significant value ( $r=.192)$. This is because the operators compete to obtain marketing place that is close to the city centre of Kuching to make it easy for tourists to visit without having to plan the tourists' travelling expenses and the quality of the transportation services because of its proximity to the city of Kuching.

The correlation test between 'Product distribution channel is the key aspect to enable products to be experienced by tourists' and 'create product cost control to remain competitive in the market' showed a positive value that is weak but significant $(r=.299, p<.01)$. This indicates that distribution channel such as wholesale and retail distribution of ecotourism products especially local handicrafts affect effective cost control in order to ensure that the handicrafts get the attention of tourists. When more product distribution channels are used, the effort to control the production cost of a product increases further. This is consistent with the results of a study by Fatimah Mohd Arshad (2006) who stated that having many intermediaries will only increase the cost of marketing and subsequently increase the price of a product and this will lead to a decline in the number of product sold.

Correlation test between 'product distribution channel is the key aspect to enable products to be experienced by tourists' and 'create product cost control to remain competitive in the market' showed a non-significant value that is $(r=.106)$, while the relationship with 'I continuously improve the quality of services and product according to the interests and preferences of the tourists' also showed a non-significant value which is $(r=.178)$. Distribution channels, such as retail and service type of business which acts as a bridge between the operators and the tourists, only functions to ensure that the information about the product sold reaches the tourists. Therefore, the aspect of cost control and quality of services do not influence the role of the distribution channel to ensure that the ecotourism products are always available in the market.

\section{Conclusion}

In order to promote the activities of ecotourism, the federal government, the state and district government continuously strive to enhance the attractiveness and competitiveness of ecotourism products. Among them is through the development of new tourism destinations. The development of new tourism destinations is proven to be successful in attracting the arrival of many local and international tourists.

Operators need to give greater focus to develop homestays since the ecotourism industry is not merely confined to islands, lakes, and beaches. Natural resources and cultural heritage that can be found in the rural areas of Kuching also have their own uniqueness and high value to be appreciated and have the potential to attract even more tourists. Through the 'inap desa' or the homestay programme, the local community or the rural community is given the opportunity to be 
jointly involved in making it a success. This can generate the economy of the local community and simultaneously assist the government in the effort to eradicate poverty and unemployment.

\section{References}

Alister \& Wall (1991) Ecotourism: Change, Ipacts, and Opportunities. The Ecotourism Equation : Measuring and Impacts.

Badaruddin Mohamed, Shida Irwana Omar, Masitah Muhibudin, Nurhashikin Shamsuddin (2009) Measuring the competitiveness of Malaysian tourism cities through the application of Multi Dimensional Scaling Analysis. Emerging Tourism \& Hospitality Trends, APTA 2009, Incheon, Korea, 9th - 12th July. pp 230-239.

Er Ah Choy, Rosniza Aznie Che Rose, Novel Lyndon, Mohd Azlan Abdullah, Adam JH (2012) Ekopelancongan dan analisis sosioekonomi komuniti Ulu Dong. Malaysia Journal of Society and Space 8 issue $9(46-52)$.

Fatimah Mohd Arshad (2006) Market Intelligence in Enhancing the Competitiveness of the Malaysian Agriculture, talking points presented at The Agriculture Consultative Panel Meeting, 1/2006, National Productivity Corporation, Petaling Jaya, 11 August.

Habibah Ahmad, Mushrifah Idris, Hamzah J., Mohd Ekhwan Toriman \& Ari Kurnia (2012) Packaging Tourism for Tasik Chini Biosphere Reserve. Journal of Social Sciences and Humanities 7(1) 2012.

Larry Steven (2009). Marketing, IMC, Advertising, Promotion, and Media.

Lee Kuok Tiung et al. (2010). Pertumbuhan dan Pelesterian Industri Ekopelancongan: Kajian Pulau Peranginan sekitar Pantai Timur Sabah. Sosiohumanika, 3(2) 2010.

Lillywhite, M., \& Lillywhite, L. (1991) Low impact tourism: coupling natural/cultural resource conservation, economic development, and the tourism industry. In J. A. Kusler (Ed.), Ecotourism and Resource Conservation: A Collection of Papers Vol. 1 (89a-89r).

Mohd. Ashari Idris \& Aliah Hanim M. Salleh (2002) Membina Integrasi arfiara Elemen Teras TQM dengan Orientasi Pasaran dan Hubungannya dengan Prestasi Firma. Jurnal Pengurusan 21 (97- 124) 2002.

Neil H . Borden (1964) The Concept of the Marketing Mix. Journal of Advertising Research (7-13)

Nor Aini Haji Idris, Faridah Shahadan, Mohd Ali Mohd Noor (2007). Malaysia ke arah hab Makanan halal Dunia. Bangi: Penerbit UKM.

Porter, M.E. 1990a. The Competitive Advantage of Nations. New York: Free Press, MacMillan.

Porter, M.E. 1990b. 'Why nations triumph', Fortune, 12 March: 94.

Redzuan Othman \& Norlida Hanim (2007) Kepentingan Beberapa Pasaran Utama Negara Asean Kepada Pembangunan. International Journal of Management Studies, 4(2) 2007.

Rosniza Aznie CR et al (2012). Persepsi pelacong terhadap agensi pelancongan di Langkawi Geopark. Malaysia Journal of Society and Space 8 issue 7 (147-154)

Shahrin Bin Hashim \& Mohammad Shaiful Nizam Bin Abu (2010) Strategi Promosi Peniaga Gerai Jualan Di Pesta Konvokesyen. 